\title{
REPORT: NATIONAL CONFERENCE ORGANISED BY THE SOUTH AFRICAN ASSO- CIATION OF WOMEN GRADUATES (SAWG), UCT MEDICAL SCHOOL, CAPE TOWN, 2 - 4 FEBRUARY 2001
}

\author{
Lydia V Monareng \\ Lecturer, Department of Advanced Nursing Science, UNISA
}

\section{INTRODUCTION}

The South African Association of Women Graduates (SAWG) is an international association that is 80 years old and is comprised of women graduates and women researchers. There are branches all over South Africa from universities and technikons. It is a multidisciplinary body with members from fields like natural sciences, humanities, education, pharmacy, statistics, occupational therapy, geomatics, biomedical sciences and nursing - just to mention a few.

\section{AIM}

The aim of the conference was to reflect on how graduate women can utilise their knowledge and research output to make a difference in their communities.

\section{EVENTS}

At $13 \mathrm{~h} 30$ there was an official opening and various research information posters were exhibited and briefly presented by the candidates. About three students presented their masters dissertations on posters. The evening banquet was graced by the presence of the Cape Town mayor. Twenty-six women researchers received awards, including Prof. Marie Muller (from Department of Nursing Science, RAU) for her outstanding contribution to research.

\section{SPEAKER PRESENTATIONS}

Prof Shirley Walters - Director: Life Long
Learning, UWC, presented a paper "Juggling with our futures: part time students speak"

The presentation focussed on the following:

- The university is mindful that to increase its services to older adult learners, it needs to change the dominant institutional culture, which favours full-time young adults.

- The majority of the students would like to study full-time but this is unaffordable; they therefore must juggle amongst the demands of their homes, work, community and the university.

- Lecturers need to demonstrate sufficient sensitivity when working with older adults.

- To take part time students seriously, it is crucial that students' perspectives are taken seriously, because for them convenience and relevance are paramount.

\section{Anita Cainross, Department Human Ecol-} ogy and Dietetics, UWC - " Factors that hamper and influence research output of women"

The presentation covered the following:

- Women are expected in a subtle way to do more of the nurturing courses such as in social sciences field rather than other challenging areas such as natural sciences, engineering and commerce - especially at masters and doctoral level.

- There is a lack of adequate mentorship, role models and support for neophyte women researchers, particularly by women.

- There is a lack of networking for research capacity building amongst women across univer- 
sities, technikons and fields of expertise.

- Women's skill to conduct creditable and objective research studies worthy to be published in accredited scientific journals is often questioned.

- Age restriction for funding is experienced by older women researchers as some funding agencies state age restrictions.

- Women are often not taken seriously in the academic circles.

- A glass ceiling on promotions or to higher-ranking positions in universities is experienced by women because of subtle discriminating barriers.

\section{Dr Succhitra Singh, School of Educational Studies, UDW - "Critical Analysis of Women Academics and Researchers in Social Sci- ences and Humanities in South Africa"}

The presenter suggested that women should:

- $\quad$ set attainable goals to produce quality work;

- reflect on their own thinking and conviction on what is to be investigated, for what purpose and at what level;

- allow their work to be challenged and critiqued by peers and other experts or professional bodies such as the National Audit of Academic Women in Research; and

- let problems and obstacles encountered in research create room for growth and development.

\section{GENERAL CONCLUSION}

- Money is essential for postgraduate women students, and a number of organisations do provide sponsorship but this information is not easily accessible to the people who need it.

- Postgraduate students ought to be involved in some ways that will empower them to develop research capability, publication skills and interest.

- Career path after doctoral studies to higher positions e.g. contract researchers should be established.
- Prominent women researchers should receive recognition as a way of motivation for them and younger researchers.

- Ways should be thought of how women post graduate students can be encouraged to pursue doctoral studies in fields like natural sciences, engineering and commerce.

- There is still a need for research mentors, role models or support programs for inexperienced women researchers other than the study leaders or promoters who are usually very busy with their own academic work and other commitments (e.g. scientific writing of dissertations or theses, how to write for publication etc.).

- Women researchers should remember to keep a balance between academic activities and family life responsibilities to avoid stress and family break down.

- It is important to focus on how research output can benefit various communities and have social relevance.

- It is interesting to note that referencing and citation of published research articles does not often indicate gender which robs astute women authors and researchers of due recognition by the readers, as very good articles are automatically assumed to be written by men.

- There is a need to identify and bring on board those potential women researchers who are in the rank and file.

- Lastly, women must learn to mentor other women as a way of passing on the legacy.

\section{CONCLUSION}

Presently the National Research Foundation (NRF) has allocated R6 million for financial assistance to those who are doing doctoral studies or for publication purposes. The SAWG is very resourceful and can provide more information on papers presented and other research related information. It has a journal that welcomes publications from women researchers or authors. A brochure providing information about the association is available. People wishing to join this association can do so by con- 
tacting the office of its president.

Contact Information:

Ms Hazel Bowen (President)

Tel./Fax (021) 447-8989

Cell 082-851 0835

E-mail: hbowen@sn.apc.org 